\title{
Fusão de protoplastos de Hevea brasiliensis Müell. Arg. e Hevea pauciflora Müell. Arg. Estabelecimento de técnica.
}

\author{
Marcel Cailloux ( $\left.{ }^{\circ}\right)$ \\ Eduardo Lleras ( ${ }^{\text {th }}$ )
}

\begin{abstract}
Resumo
É descrita uma técnica para obtençāo de pro. toplastos de folhas de Hevea, assim como um procedimento para determinar fusão de protoplastos de duas espécies.
\end{abstract}

\section{INTRODUÇño}

Os clonos mais produtivos de látex de Hevea brasiliensis não podem ser cultivados como monocultura no Brasil devido a presença de um fungo, Microcyclus ulei, que infesta as folhas novas e eventualmente causa a murcha das mesmas. Na floresta amazônica, o habitat natural de Hevea brasiliensis, o fungo causa danos limitados sendo que só existem umas 5-7 árvores da espécie por hectare. Estão assim isoladas umas das outras e, conseqüentemente, parcialmente protegidas dos esporos de M. ulei. Além disto, estas árvores predominantemente pouco produtivas são relativamente tolerantes à doença. Em contraste, as árvores mais produtivas de Hevea são mais susceptíveis. Quando são plantadas próximas umas das outras em plantações, esta característica facilita a dispersão da doença e diminui granmente a viabilidade de produção em larga escala de borracha nas Américas.

Existem espécies de Hevea tolerantes ao ataque por Microcyclus ulei. Hevea pauciflora é um extraordinário exemplo disto. Porém, esta espécie tem uma produção de borracha muito baixa. Cruzamentos entre Hevea brasiliensis e $\mathrm{H}$. pauciflora poderiam ser conseguidos talvez, para tentar obter um hibrido resistente à doença e de alta produtividade. Esta técnica, porém, é difícil por muitas razões. As principais destas são: os mecanismos de isolamento e a segregação de cromossomos nãc homólogos (que pode ser contornado com poliploidia).

A nova técnica de hibridização somática através de fusão de protoplastos pode possivelmente ser uma alternativa viável. Já têm sido obtidos híbridos somáticos nas Solana. ceae (por exemplo Tomate x Batata), e não há razões teóricas pelas quais não possam ser obtidos em outras familias. Assim, têm-se iniciado, com o presente trabalho, pesquisas na hibridização somática de Hevea.

\section{MATERIAIS E MÉTODOS}

\section{a. SOLUÇÃo NUTRITIVA}

Para a cultura de protoplastos de Hevea é utilizado o meio nutritivo completo $T_{0}$ descrito por Bourgin et al. (1976). Sua composição é a seguinte :

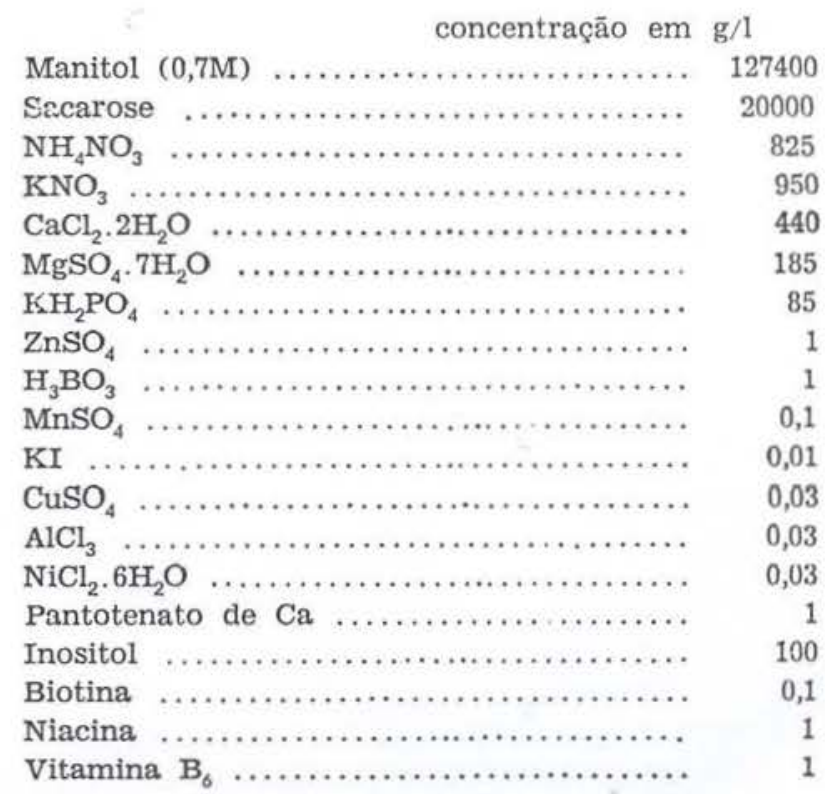

(*) - Department des Sciences Biologiques, Université de Montreal, Montreal, Canadá (*) - Instituto Nacional de Pesquisas da Amazônia, Manaus. 
Vitamina $B_{1}, \ldots \ldots \ldots \ldots \ldots \ldots \ldots \ldots \ldots \ldots \ldots$

Ácido Naftalono-acético ................ 3

Benzyl Adenina ....................... 3

Fe ..... $5 \mathrm{ml}$ de solução "stock", contendo:

$5,57 \mathrm{~g} \mathrm{Fe}_{2} \mathrm{SO}_{4} \cdot 7 \mathrm{H}_{2} \mathrm{O}+7,45 \mathrm{Na}_{2}$ EDTA até um litro de água.

Nesta solução nutritiva os macro-elementos são os de Murashige-Skoog (1962) diluídos à metade; os micro-elementos são os de Heller (1953), onde o $\mathrm{FeCl}_{3}$ é substituído por Fe EDTA e as vitaminas são as de Morel e Wetmore (1951).

\section{b - MEIO DE MACERAÇÃO}

Este meio está composto de solução $T_{0}$ na qual é omitida a sacarose e as enzimas apropriadas na proporção certa. Para Hevea brasiliensis o meio de maceração é composto das seguintes substâncias :

Celulase Onozuka $\mathrm{R}_{\mathrm{i0}}$ (1) ....... $0,4 \%$

Driselase ${ }^{(2)} \ldots \ldots \ldots \ldots \ldots \ldots \ldots \ldots, 0,2 \%$

Macerozima $\mathbf{R}_{10}$ (1) $\ldots \ldots \ldots \ldots \ldots, 0,08 \%$

Para Hevea pauciflora o meio de maceração foi o seguinte :

Celulase Onozuka $R_{10} \ldots \ldots \ldots \ldots .0,3 \%$

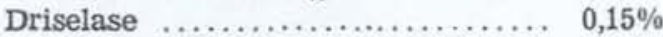

Macerozima $R_{10} \ldots \ldots \ldots \ldots \ldots \ldots, 0,06 \%$

Os meios de maceração são inicialmente filtrados através de papel de filtro comum e logo esterilizados por filtração por meio de um filtro miliporo de $0,25 \mu \mathrm{m}$. Estes meios estão calculados para maceração durante a noite como descrito por Chupeau et al. (1974) e são ajustados para obter maceração apropriada para tiras de folha de Hevea (ver discussão).

\section{C - TÉCNICA DE OBTENÇÃO DE PROTOPLASTOS DE HEVEA}

Folhas jovens de Hevea são esterilizadas superficialmente por 15 minutos em uma solução comercial de hipoclorito de sódio (QBOA) a $10 \%$ à qual tem sido adicionadas 10 gotas de um detergente líquido de uso doméstico (Espuma Limão) para cada $500 \mathrm{ml}$ de solução. As folhas são logo lavadas três vezes com água esterilizada. As folhas molhadas são colocadas sobre papelão estéril e cortadas em tiras de $1 \mathrm{~mm}$ de largura com seis lâminas de barbear (gilette) igualmente espaçadas umas das outras. Uma ferramenta em forma de "L" com sua parte horizontal coberta de borracha é usada para segurar a folha quando as tiras são cortadas. As tiras são cortadas começanclo da nervura central para as margens. As folhas aderem melhor ao papelão e são mais fáceis de cortar. Se a largura da folha, da nervura à margem é maior que $4 \mathrm{~cm}$, o excesso é tirado com um bisturi. As tiras são entre 3 e $3,5 \mathrm{~cm}$ de comprimento. As tiras são colocadas à flutuar imediatamente em $10 \mathrm{ml}$ do meio de maceração em placas de petri de $10 \mathrm{~cm}$ de diâ. metro.

Após pernoitar (14-16 horas) na temperatura de laboratório (aqui em Manaus aproximadamente $24^{\circ} \mathrm{C}$ ), as placas de Petri são agitadas suavemente com movimento rotário horizontal para liberar os protoplastos.

\section{d - Cultura dos potoplastos}

Os protoplastos são pipeteados lentamente das placas de Petri e colocados em tubos estéreis de centrífuga com tampa de rosca. São logo centrifugados a menos de $100 \mathrm{~g}$ (aproximadamente 800 revoluções por minuto) durante 5 minutos. O líquido sobrenadante é trocado por $10 \mathrm{ml}$ de $T_{0}$ e os protoplastos postos novamente em suspensão. Isto é repetido três vezes até que o meio de maceração esteja diluído pelo menos $1000 \mathrm{X}$.

Quando são desejadas culturas líquidas, 2 $\mathrm{ml}$ da suspensão lavada de protoplastos, contendo aproximadamente $6 \times 10^{6}$ protoplastos por $\mathrm{ml}$ são colocadas em placas de Petri de $5 \mathrm{~cm}$ de diâmetro. A cultura sólida é obtida misturando $1 \mathrm{ml}$ da suspensão de protopiastos com $1 \mathrm{ml}$ de agar a $0,8 \%$ mantido a $45^{\circ} \mathrm{C}$. As culturas são mantidas à temperatura de laboratório $\left(24^{\circ} \mathrm{C}\right)$ ou sujeitas às flutuaçōes normais de temperatura da região Amazônica (que variou entre 23 e $33^{\circ} \mathrm{C}$ durante nossos expcrimentos), sob luz difusa. Os exames para detectar divisão celular são feitos após quatro dias.

\section{e - DETERMINAÇÃO DE FUSÃo INTERESPECÍFICA DE PROTOPLASTOS DE HEVEA}

Os protoplastos das duas espécies de Hevea são indistingũíveis uns dos outros. Para poder determinar a fusão entre as duas espécies é preciso ter um marcador. Neste caso, 


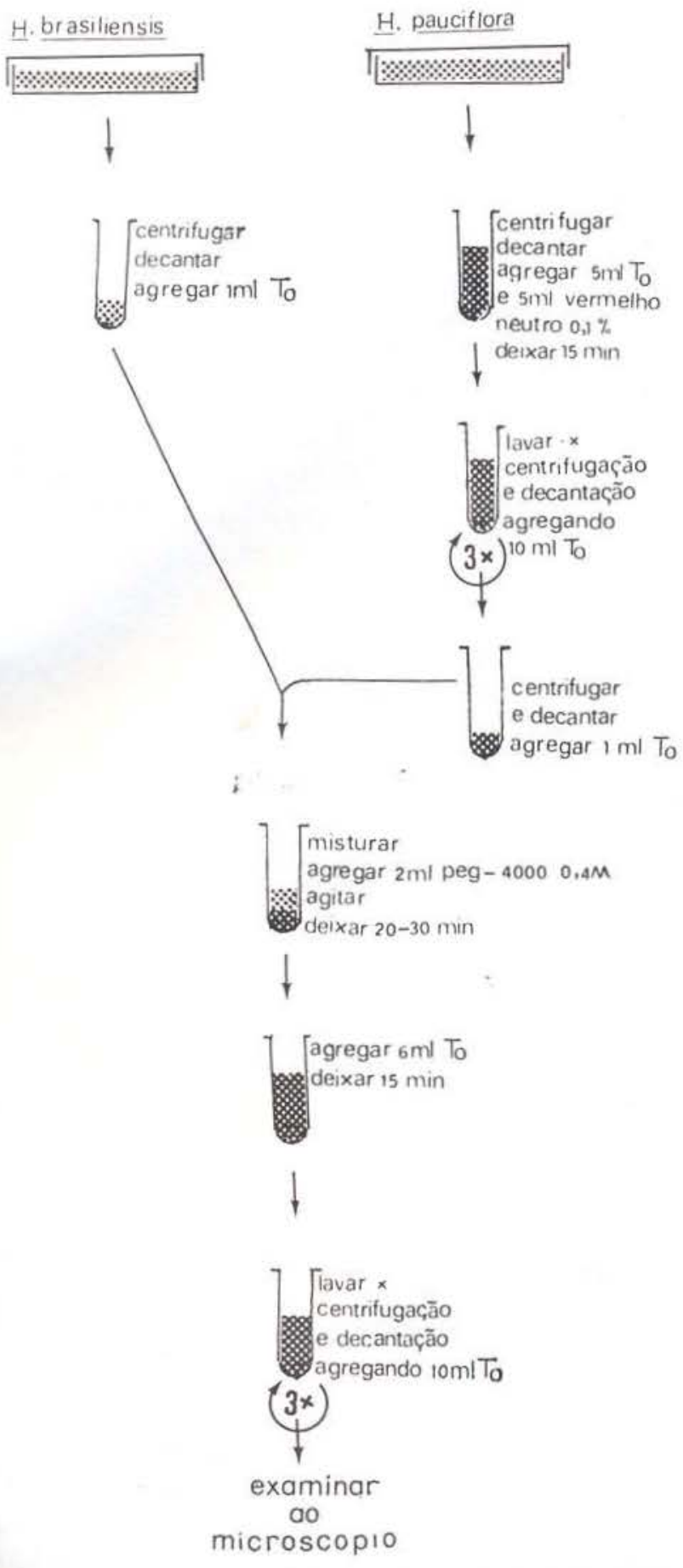

Fig. 1 - Protocolo de determinação de Fusão Interespecífica de Protoplastos de Hevea brasiliensis e H. pauciflora.

um coranie vital, vermelho neutro é usado como marcador para tingir os protoplastos de uma das duas espécies. Glicol de Polietileno (PEG 4000) é o agente de fusão. A técnica ge- ral é uma modificaçăo da usada por Erikson et al. (1974). Está ilustrada na figura 1 e detalhada a seguir.

Inicialmente as tiras de folha de Hevea brasiilensis e $H$. pauciflora são maceradas durante a noite em suas placas de Petri respectivas. As suspensões de protoplastos resultantes são pipetadas nos respectivos tubos de centrífuga e centrifugados a $70 \mathrm{~g}$ por cinco minutos. Após decantar o líquido sobrenadante, os dois tubos recebem tratamentos diferentes. Um $\mathrm{ml}$ de $\mathrm{T}_{\mathrm{o}}$ é agregado ao tubo de $\mathrm{H}$. brasiliensis e o tubo é deixado a um lado até o momento de fazer a fusão. No tubo contendo os protoplastos de $H$. pauciflora são colocados primeiro 5 $\mathrm{ml}$ de $\mathrm{T}_{0}$ e logo $5 \mathrm{ml}$ de uma solução de verme. Tho neutro a $0,1 \%$. Os protoplastos săo leva. dos a suspensão agitando suavemente e deixados por 15 minutos. O tubo é centrifugado três vezes a $70 \mathrm{~g}$ por 5 minutos, cada vez com decantação, descartando o sobrenadante e adicionando $10 \mathrm{ml}$ de To. Após uma quarta centrifugação e decantação, somente é agregado 1 $\mathrm{ml}$ de To.

Os protoplastos das duas espécies estäo agora prontos para iniciar a fusāo. Para iniciar fusão, misturar primeiro os protoplastos dos dois tubos e agregar $2 \mathrm{ml}$ de PEG 4000 0,4 M. Agitar suavemente e deixar por 20-30 minutos. Lavar uma vez por centrifugaçäo decantando $\mathrm{e}$ adicionando $10 \mathrm{ml}$ de $\mathrm{T}_{\mathrm{o}}$. Deixar por 15 minutos . (a maior parte da fusão ocorre nesta fase). Lavar duas vezes por centrifugação, decantação e adição de $10 \mathrm{ml} \mathrm{T}$. Examinar ao microscópio para determinar o grau de fusão interespecifica. Se os resuitados são satisfatórios, repetir, omitindo o processo de coloração para cultivar os produtos de fusão.

\section{DISCUSSÃo DO MÉTODO}

Quanto mais novas forem as folhas, maior será o número de protoplastos obtidos por grama de peso fresco de tecido à uma concentração dada de enzimas macerantes. O tamanho das folhas não é tomado como indicação da idade fisiológica das mesmas. Folíolos de $12-18 \mathrm{~cm}$ de comprimento coletados no campo de enxertos de 2 anos são escolhidos para Hevea brasiliensis. Folhas de $\mathrm{H}$. pauciflora nas mesmas condições tendem a ser muito maio- 
res. As folhas novas são flácidas e parecem estar penduradas pelo pecíolo. As folhas mais maduras são mais rígidas e dão menos protoplastos (tabela 1). Quando maduras são quebradiças e fazem $\alpha$ som característico de vidrc fino sendo quebrado quando são cortadas em tiras com lâminas de barbear. A produção por grama de peso fresco das folhas novas normalmente atinge $1 \times 10^{3}$ protoplastos nos meios de maceração com as concentrações de enzimas escolhidas para Hevea. Aproximadamente 0,75 gramas de tiras de folhas são usadas para cada placa de Petri de $10 \mathrm{~cm}$ de diâmetro.

A concentração osmótica de manitol tem que ser ajustada à idade fisiológica das folhas. Por exemplo, ainda se mais protoplastos são obtidos a $0,7 \mathrm{M}$ que a $0,55 \mathrm{M}$, só a metade dos protoplastos são perfeitamente esféricos à concentração de 0,7M. Esfericidade e lisura do contorno comparados com forma e contornos irregulares são tomados aqui como critérios para determinação de protoplastos sadios.

TABELA 1 - Quantidade de protoplastos por $\mathrm{ml}$ de meio de maceração em função da idade fisiológica das folhas.

\begin{tabular}{|c|c|c|c|}
\hline $\begin{array}{l}\text { Comprimento de } \\
\text { folhas }\end{array}$ & $\begin{array}{l}\text { relativa } \\
\text { rigidez }\end{array}$ & \multicolumn{2}{|c|}{$\begin{array}{l}\text { protoplastos } \\
\text { por } \mathrm{ml}\end{array}$} \\
\hline $18 \mathrm{~cm}$ & flácida & 6 & $\times 10^{6}$ \\
\hline $18 \mathrm{~cm}$ & $\begin{array}{l}\text { ligeiramente } \\
\text { rígida }\end{array}$ & 3,5 & x $10^{6}$ \\
\hline $23 \mathrm{~cm}$ & flácida & 2,85 & $\times 10^{6}$ \\
\hline $20 \mathrm{~cm}$ & $\begin{array}{l}\text { ligeiramente } \\
\text { rígida }\end{array}$ & 2 & x $10^{6}$ \\
\hline
\end{tabular}

Não há uma concentração absoluta de enzimas que seja melhor em todas as situações. As concentrações maiores produzem mais protoplastos. Porém, deve-se lembrar que as enzimas não são puras e podem assim apresentar alguma toxicidade aos protoplastos.

A menor concentraçăo de enzimas, que produz um número suficiente de protoplastos, deve ser usada. A figura 2 indica a relação entre o número de protoplastos obtidos e a concentração de enzimas do meio de maceração. Aqui, a concentração de enzimas usada por Chupeau et al. (1974) é usada como ponto de comiparação (IX) .
Pode-se ver que Hevea pauciflora produz mais protoplastos por $\mathrm{ml}$ de solução de maceração que $H$. brasiliensis e que o número de protoplastos produzidos começa a diminuir à concentrações de $4 \mathrm{X}$ para $H$. brasiliensis. Assim, escolhemos $4 \mathrm{X}$ para $H$. brasiliensis e $3 \mathrm{X}$ para $H$. pauciflora, sendo que estas duas concentrações dão respectiva e aproximadamente o mesmo número de protoplastos.

Para avaliar a eficiência relativa de cada enzima no meio de maceração, as enzimas têm sido testadas individualmente e em diversas combinações. Os resultados são apresentadơs na Tabela 2. A celulase, quando usada independentemente, apresenta atividade muito baixa Driselase, usada independentemente, é 13 vezes mais ativa, mas em combinaçăo estas duas enzimas liberam quase $2 / 3$ dos protopiastos. quando comparado com uma mistura completa de enzimas.

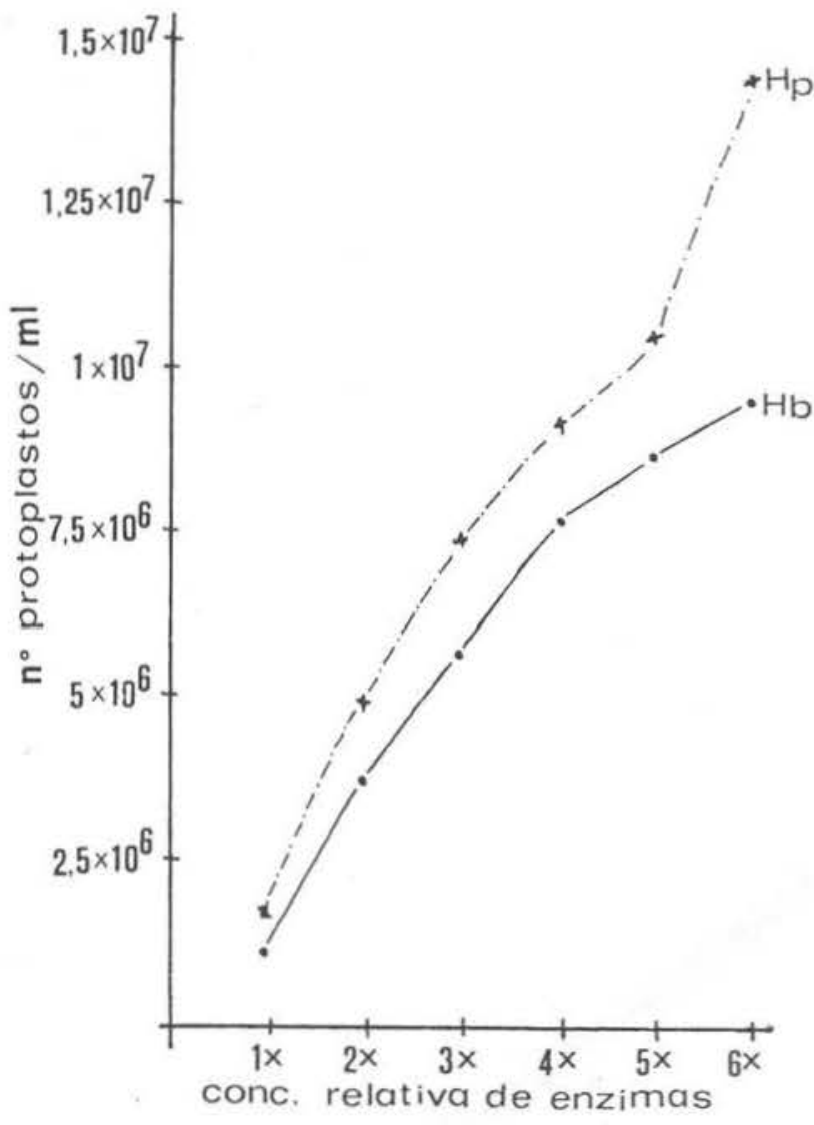

Fig. 2- Efeito da concentraçāo de enzimas de maceração na produção de protoplastos de Hevea. A referência (IX) é a concentração usada por Chupeau et al. (1974) para tabaco. Hb, H. brasiliensis; Hp, H. pauciflora. 
TABELA 2 - Papel sobre Hcvea pauciflora de cada enzima na mistura usada por Chupeau et al. (1974) em tabaco. A concentração de referência é $3 x$. A eficiência é expressada como número de proloplastos obtidos por $\mathrm{ml}$. de meio de maceração.

\begin{tabular}{|c|c|c|c|c|c|c|c|}
\hline \multirow[t]{2}{*}{ Enzima } & \multicolumn{7}{|c|}{$\mathrm{mg}$ de enzima por $10 \mathrm{ml}$ de $\mathrm{T}$ 。 } \\
\hline & 30 & 30 & 30 & 15 & $\rightarrow$ & $一$ & 15 \\
\hline Driselase & - & 15 & 15 & 15 & 15 & 15 & 7 \\
\hline Macerozima & $\rightarrow$ & 一 & 6 & 6 & 6 & $\rightarrow$ & 6 \\
\hline Número de prcíoplastos $/ \mathrm{ml}$. & $3,5 \times 10^{5}$ & $5 \times 10^{6}$ & $6,8 \times 10^{6}$ & $6,3 \times 10^{6}$ & $4,6 \times 10^{6}$ & $4,7 \times 10^{6}$ & $3,1 \times 10^{6}$ \\
\hline
\end{tabular}

Uma terça parte da atividade de maceração é devída à ação da Macerozima. Reduzindo-se à metade a concentração de celulase ou driselase, reduz-se consideravelmente a eficiência da mistura. Assim, as proporções relativas de enzimas usadas por Chupeau et al. (1974) em folhas de tabaco são também válidas para Hevea e só a concentração das mesmas tem que ser aumentada.

A fusão de protoplastos de Hevea não apresenta grandes problemas já que obtivemos entre $7,5 \times 10^{5}$ e $1,12 \times 10^{6}$ fusões por $\mathrm{ml}$, o que equivale a um índice de fusão de entre 10 a $15 \%$. Percentagens idênticas foram encontradas por Kao \& Michayluk (1974) e Erikon et al. (1974). Eles consideram esta percentagem de fusão como sendo de alta frequência. Sendo que temos obtido divisão celular em protoplastos individuais de Hevea tanto em cultura líquida quanto sólida, e sendo que Hevea apresenta um grande potencial para regeneração celular em enxertos, as perspectivas de obter regeneração de plantas completas a partir de produtos de fusão parecem ser uma meta alcançável.

\section{AGRAdecimentos}

Agradecemos de maneira muito especial a todo o pessoal técnico do Instituto Nacional de Pesquisas da Seringueira que deu todo o apoio à nossa pesquisa. Agradecemos também à Dra. Rosemary Silvester Bradley e ao Dr. Theodore Verne St. John pelo gentil empréstimo de equipamento e laboratório.

\section{SUMMARY}

A technique for obtaining protoplasts from Hevea leaves is described together with a procedure to ascertain the fusion of the protoplasts of two species, Hevea brasiliensis and $\mathrm{H}$. pauciflora.

\section{BIBLIOGRAFIA}

Bourgin, J.P.; Missonier, C. \& Chupeau, Y.

1976 - Culture de protoplastes de mésophylle de Nicotiana sylvestris Spegazzini et Comes haploide et diploide. C. R. Acad. Sc. Paris. Série D, 282 : 1853-1856.

Chupeau, Y.; Bourgin, J.P.; Missonier, C.; Dorion. N. \& MOREL, G.

1974 - Préparation et culture de protoplastes de divers Nicotiana. C. R. Acad. Sci. Paris. Série D, $278: 1565-1568$.

ERikson, T.; Bonnett, H.; Glimelius, K. \& Wallin, A. 1974 - Technical advances in protoplast isolation, culture and fusion. In: "Tissue Culture and Plant Science" edited by H. E. Street. London, New York, San Francisco. p. 213-231.

HELler, $\boldsymbol{R}$.

1953 - Recherches sur la nutrition minérale des tissus vegetaux cultivés in vitro. Thesis \& Ann. Sci. Nat. Bot. Biol. Vég., Paris, $14: 1-223$.

KAO, K.N. \& MichaYLUK, M.R.

1974 - A method for high frequency intergeneric fusion of plant protoplasts. Planta, $115: 355-367$.

MOREL, G. \& WeTMORE, R.H.

1951 - Tissue culture of monocotyledons. Amer. Jour. Bot., 38 : 138-140.

Murashige, T. \& SkoOG, F.

1962 - A revised medium for rapid growth and bioassays with tobaco tissue cultures, Physiol. Plantarum, 15:473-497.

(Aceito para publicação em $5 / 12 / 78$ ) 